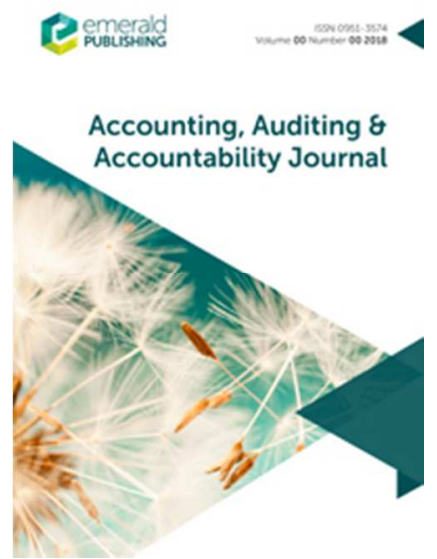

\title{
Investigating the Backstage of Audit Engagements: The Paradox of Team Diversity
}

\begin{tabular}{|r|l|}
\hline Journal: & Accounting, Auditing \& Accountability Journal \\
\hline Manuscript ID & AAAJ-08-2016-2666.R3 \\
\hline Manuscript Type: & Research Paper \\
\hline Keywords: & $\begin{array}{l}\text { paradox theory, audit engagement team, team diversity, reduced audit } \\
\text { quality practices, auditors coping strategies }\end{array}$ \\
\hline \multicolumn{2}{|l}{} \\
\hline
\end{tabular}

\section{SCHOLARONE ${ }^{\text {Im }}$}




\section{Introduction}

Audit assignments require the processing and analysis of large amounts of information in order to reach a reflective judgment on which to base decisions (Pentland, 1993). As such, audit is a collective process, typically conducted by a team of individuals with differing skills and experience. The diversity of the audit team may have both positive and negative consequences (Bamber, 1983). It is such consequences that we explore in this paper.

Power (2003 p. 379) argues that we ought to question the 'rationalized accounts of the audit process and explore the complex backstage of practice'. Almost twenty years on, we believe that this backstage of audit practice remains underexplored, perhaps because of the hidden nature of much audit work which typically takes place within the client organisation (Malsch et al., 2013, Malsch and Guénin-Paracini, 2013, Sweeney and Pierce, 2011). In addition, we note that much audit research has been conducted using what appears as emotionless algorithmic reasoning (Guénin-Paracini et al., 2014, Francis, 1994), whilst research on audit 'field work' and the social and contextual aspects of such work has been neglected (Pentland, 1993, Peecher et al., 2007). For example, McPhail (2004) and Nelson and Tan (2005) both note the lack of research into the emotional dimensions of audit work and the sources of stress in the auditors' role (Smith et al., 2010).

In response to this gap in the literature, our research focuses on looking behind the audit veil' (Bamber et al. (1998) to illuminate 'the backstage of audit work'. We investigate the challenges in audit work and how auditors' respond to the recurring contradictory pressures and opposing demands that arise in the course of their work. More specifically, this paper seeks to answer questions about how the audit team respond to differing contextual conditions, and how team members manage the group dynamics, and any team conflicts and tensions that they encounter. The focus is on the implications of both organisational context and group dynamics on audit quality.

The labour intensive nature of audit work results in high staff costs (Rich et al., 1997, Bamber and Ramsay, 2000). Aggressive pricing by audit firms (McNair, 1991, Pierce and Sweeney, 2004, Sweeney and Pierce, 2004) may also place pressures on audit engagement work. An audit team's efforts to achieve tight time and cost targets may result in compromises in audit quality (Beattie and Fearnley, 1998, AICPA, 1978, Rhode, 1978, Sweeney and Pierce, 2011, McNair, 1991). Auditors may also face conflicting commercial and professional goals (Suddaby et al., 2009, Picard et al., 2014, Sweeney and McGarry, 2011). This conflict may lead to them engaging in reduced audit quality practices (RAQP), typically defined as intentional actions taken by an auditor during an engagement which reduce acceptable standard of audit quality (Kasigwa et al., 2013, Coram et al., 2000, Herrbach, 2001, Solomon, 1987, Bamber, 1983, Yuen et al., 2013).

To date, research into audit practice has focused on the private sector. The public service context is both interesting and arguably more complex than the non-profit or private sector (Arnaboldi et al., 2015); (Bracci et al., 2015, Hood and Dixon, 2015) and is typically bounded by restrictive standards of efficiency and effectiveness (Humphrey et al., 1993, Ellwood and Newberry, 2007). Public sector audit and the challenges faced by public sector audit teams have remained relatively under-researched. This paper addresses this through a field based study of audit teams in the Indonesian Audit Body (IAB).

Our case study investigates how paradoxical conditions influence audit teamwork. We offer evidence to suggest that RAQP are an inevitable consequence of paradoxical situations. In our research we focus on resource constraints and the associated controls that may encourage rather than eliminate RAQP. We do not extol the virtues of control practices, as a solution, but rather work toward a position that accepts that control actions inevitably cause 
tensions, which may be the immediate cause of RAQP. Our findings therefore have implications for both private and public sector audit teams.

As already noted, audit teams are commonly made up of staff with different individual characteristics, values, experience and motivations. Paradox Theory suggests that the requirement associated with team diversity and the demand to achieve team cohesion may emerge and persist in team work processes (Smith and Tracey, 2016, Smith and Lewis, 2011). We use this theory to analyse the behaviour of the audit teams in our field sample. Paradox Theory enables us to understand how an audit team responds to the conflicting demands of diversity versus cohesion in an environment that is also characterised by limited resources and inadequate audit planning. As a result we find that the backstage of government audit work can exhibit RAQP, which are a direct response to the paradoxes faced by the audit team. This offers a characteristic paradoxical situation where the pressures to complete the audit create the pressure that leads to RAQP.

Our paper contributes to the literature by offering insights into the micro-sociological aspects of audit team work in a government audit setting. We also expand the literature on auditors' reactions/coping strategies as they respond to conflicts (Sweeney and Pierce, 2011, Sweeney and Pierce, 2006, Herrbach, 2005), by uncovering the cascading responses to paradox of team diversity. These strategies are performed concurrently by team leaders and audit members to manage paradoxical tensions. In commenting on the impact of resource shortages, we also expand the literature on inadequate supervision as one of the factors driving RAQP (Rhode, 1978, Alderman and Deitrick, 1982, Otley and Pierce, 1996, Herrbach, 2001).

The paper is structured as follows. Firstly, we explain how paradox theory can provide a useful lens to explore the audit environment Secondly, we discuss the methods used in this research and the research context. Next we present the findings, in which we detail how organizational complexities can magnify the paradoxes arising from team diversity. The analysis portrays persistent contradictions between team diversity and team cohesion leading to cascading RAQP. The paper ends with a summary of the conceptual and practical implications of our research findings in the discussion and conclusion.

\section{Paradox Theory and Audit Team Dynamics}

The word "paradox" is derived from a Greek word, "paradoxos", meaning contrary to expectation (Eisenhardt and Westcott, 1988). Although paradox can be considered to have numerous meanings, common definitions refer to the existence of contradictory actions, oppositional tendencies, or polarities. Philosophers from ancient Greece to the Existentialists have recognised paradox in human life such as tensions between life and death, self and other, good and evil (Hampden-Turner, 1981, Schneider, 1990, Lewis, 2000).

Paradoxes are different to dilemmas and dualities. Dilemma has been described as contradictory elements where each competing alternative poses clear advantages and disadvantages or involves weighing pros and cons (Smith and Lewis, 2011, McGrath, 1982). A duality represents an interdependent relationship between contradictory elements that are mutually constituted and ontologically inseparable. In dualities it is almost impossible to describe one element without the other and the tension is resolved through integration (Smith and Graetz, 2006, Schad et al., 2016, Smith and Lewis, 2011). In a contemporary context, paradox is described in a processual assumption (Smith and Tracey, 2016) as shown Figure 1 below. 
Figure 1 Underlying and processual assumption of paradox theory (Smith and Tracey, 2016)

\begin{tabular}{|c|c|c|}
\hline & Processual view of the paradox & Audit context \\
\hline $\begin{array}{l}\text { Source of } \\
\text { paradox }\end{array}$ & $\begin{array}{l}\text { Inherent contradictions in organizations, } \\
\text { emerging through the acts of } \\
\text { organizations, relational dynamics, } \\
\text { individual sensemaking, increased } \\
\text { environmental plurality or scarcity of } \\
\text { resources. These contradictions result in } \\
\text { growing complexity in organizations. }\end{array}$ & $\begin{array}{l}\text { Increased environmental complexity in audit } \\
\text { assignment (Prawitt, 1995), increased task } \\
\text { complexity and demands on auditors decision } \\
\text { making and cognitive capacity (Bonner, 1994, } \\
\text { Trotman et al., 2009, Rich et al., 1997, Griffith et } \\
\text { al., 2015, Dowling, 2009) }\end{array}$ \\
\hline $\begin{array}{l}\text { Emergence } \\
\text { of paradox }\end{array}$ & $\begin{array}{l}\text { Paradox emerges when organizations } \\
\text { stimulate distinction between } \\
\text { contradictory elements, and maintain the } \\
\text { oppositional, conflictual, inconsistent, and } \\
\text { interdependent nature of the elements. } \\
\text { Organizations embed contradictory } \\
\text { elements in the system, making them } \\
\text { persist overtime. }\end{array}$ & $\begin{array}{l}\text { Cost-quality conflicts (Pierce and Sweeney, 2004, } \\
\text { DeAngelo, 1981, Watkins et al., 2004, McNair, } \\
\text { 1991), resources/infrastructures versus risk } \\
\text { mitigation/strategic system (Beattie and Fearnley, } \\
\text { 1998, AICPA, 1978, Rhode, 1978, Curtis and Turley, } \\
\text { 2007, Turley and Cooper, 1991), auditors diversity } \\
\text { and cross-cultural collaboration (Pentland, 1993, } \\
\text { Rich et al., 1997, Bamber and Ramsay, 2000) }\end{array}$ \\
\hline $\begin{array}{l}\text { Responses } \\
\text { to paradox }\end{array}$ & $\begin{array}{l}\text { The contradictions of paradoxical elements } \\
\text { cannot be resolved and provoke dynamic } \\
\text { interactions that require ongoing } \\
\text { processual responses. }\end{array}$ & $\begin{array}{l}\text { Defensive responses against groupthink (Parker, } \\
\text { 1990), coping mechanism to avoid embarrassment } \\
\text { or threat, and to gain acceptance (Herrbach, 2005, } \\
\text { Sweeney and Pierce, 2011, Sweeney and Pierce, } \\
\text { 2006), transactional or passive avoidance } \\
\text { responses (Notgrass et al., 2013) }\end{array}$ \\
\hline
\end{tabular}

\subsection{The source of paradox}

Paradox is defined as persistent contradiction between interdependent elements that (1) appear logical when in isolation, but inconsistent, irrational and absurd when juxtaposed; and (2) induce responses that embrace tensions simultaneously (Lewis, 2000, Smith and Lewis, 2011, Putnam et al., 2016). Paradoxes involve the existence of contradictory and oppositional elements that persist and are usually inherent in systems, but are often latent and unobserved (Smith and Lewis, 2011, Schad et al., 2016). Latent paradoxical elements become salient to actors due to individual sensemaking, relational dynamics or through environmental conditions of scarcity/limited resources, plurality, and change (Putnam et al., 2016, Smith and Tracey, 2016, Smith and Lewis, 2011).

In the audit context, the increased environmental complexity in audit assignments (Prawitt, 1995) has been identified as a source of paradoxical conditions, as task complexity and demands on auditors' decision making and cognitive capacity are increased over time (Bonner, 1994, Trotman et al., 2009, Rich et al., 1997, Griffith et al., 2015, Dowling, 2009). Auditors do not work in isolation, highlighting the importance of understanding the influence of auditors' interactions with the people, tasks and environment with which they interact (Humphrey et al., 1993).

\subsection{The emergence of paradox}

Paradoxes emerge when an organizational setting stimulates distinctions, creates oppositions, and embeds contradictory elements within a system (Smith and Tracey, 2016). The contradictory elements may become increasingly prominent and persistent in a dynamic and complex organisation (Lewis, 2000). Schad et al. (2016) in exploring the nature of paradox, considers paradox as a noun, which refers to concrete, discernable contradictions. 
The contradictory features or elements exist and persist simultaneously and synergistically: over time (Putnam et al., 2016, Schad et al., 2016, Smith and Lewis, 2011); through reflection or interaction (Ford and Backoff, 1988). These manifest in organisational efforts in collaboration versus control (e.g. Sundaramurthy and Lewis, 2003), the individual against the collective (e.g. Murnighan and Conlon, 1991), or flexibility and efficiency (e.g. Smith and Tushman, 2005).

These contradictory elements are likely to become increasingly exposed and reflect back on each other, subsequently developing into seemingly irrational or absurd situations. In an audit context, paradox arises from cost-quality conflicts (Pierce and Sweeney, 2004, DeAngelo, 1981, Watkins et al., 2004, McNair, 1991), and contradictions between resources/infrastructures versus risk mitigation/strategic systems (Beattie and Fearnley, 1998, AICPA, 1978, Rhode, 1978, Curtis and Turley, 2007, Turley and Cooper, 1991). In the context of audit in public sector, contradictions between independence/neutrality from the executive and political mandates/approvals fuels the emergence of paradox (Gendron et al., 2001, Power, 1999, Gendron et al., 2007, Radcliffe, 1997, Funnell, 2004, Funnell, 1998, Skærbæk, 2009).

Paradox also emerges within audit team dynamics as supervisors and managers seek to maintain diversity of capabilities, identity and cross-cultural collaboration (Pentland, 1993). An audit team may be seen as unique because it is generally small in size, is required to function for only a short duration and must rapidly coalesce to achieve its objectives (Rich et al., 1997, Bamber and Ramsay, 2000). The cohesiveness of the team is crucial in managing the interdependencies of team work and the need for knowledge sharing across diverse expertise (Pentland, 1993). Team cohesion can be defined as 'a dynamic process that is reflected in the tendency for a group to stick together and remain united in the pursuit of its instrumental objectives and/or for the satisfaction of member affective needs' (Carron et al., 1998 as cited in Gammage et al. 2001, 3).

Audit team cohesion involves a significant level of trust and engagement on the part of team members (Rich et al., 1997, Bamber and Ramsay, 2000). Cohesion requires interpersonal attraction, commitment to the task and group pride among diverse members (Beal et al., 2003, Mullen and Copper, 1994). Diversity within teams can be seen as a doubleedged sword, which leads to both positive and negative effects simultaneously (Pieterse et al., 2013, Srikanth et al., 2016). While diversity can encourage creativity and possibly better solutions, it can also be damaging in reducing cohesion and information sharing. The contradictions between team diversity and team cohesion affects the individuals' ability to conform to group norms and concentrate on synergetic interactions (Beal et al., 2003, Gammage et al., 2001).

\subsection{Responses to paradox}

When team members interact, tensions and conflicts may arise that are hard to manage and that may prevent collective goals from being achieved (Ford and Backoff, 1988). This can create unfavourable conditions such as a lack of coordination and also poor communication. These conditions could be caused by contradictory pressures, such as involvement versus detachment within the team (e.g. Sundaramurthy and Lewis, 2003, Vince and Broussine, 1996, Gibbs, 2009). In paradoxical situations, actors cannot avoid and resolve the contradictions of paradoxical elements in increasingly complex organizational environments.

These paradoxical situations require ongoing processual responses (Smith and Tracey, 2016). Lewis (2000) discusses how paradoxes create reinforcing cycles, which require responses or actions to manage them (Lewis, 2000, Cameron and Quinn, 1988). In these circumstances, actors' responses to the tensions may be a critical factor for the destiny of the organisation (Cameron and Quinn, 1988). Paradoxes could be seen as challenges and 
opportunities, resulting in defensive responses to reject and resist paradoxes (Lewis, 2000), or alternatively foster creativity, and enable long-term sustainability (Smith and Tracey, 2016, Smith and Lewis, 2011). In the audit context, conflict within audit teams can have both positive and negative influences. Positive outcomes may help to promote creativity, provide new solutions and better decision-making, in addition to encouraging learning and knowledge sharing (Amason et al., 1995, Jehn, 1995, Notgrass et al., 2013).

Conflict and contradictions between team diversity and team cohesiveness may also trigger defensive responses against groupthink (Parker, 1990), potentially leading to unsupported decisions (Notgrass et al., 2013). In contrast, conflict in its negative guise is more concerned with the inability of the audit team to discuss issues in order to achieve an optimal resolution, the avoidance of important issues and potentially a splitting of the team into different factions or sub-groups. Auditors might employ coping mechanisms to deal with these conflicts, to avoid embarrassment or threat, and to gain acceptance by the organisation (Herrbach, 2005, Sweeney and Pierce, 2011, Sweeney and Pierce, 2006). In this case, auditors modify the work they perform to manage the perceived engagement constraints.

Notgrass et al. (2013) suggests that as conflict increases a team leader with a transactional style might search for alternative opinions from the team, propose new ways of examining assignments, and try to account for moral and ethical consequences of decisions. In the audit context, the conflict between diverse team members and team cohesiveness might impact on the level of audit quality. Auditors might get involved in dysfunctional behaviour (Solomon, 1987, Bamber et al., 1998), or quality threatening behaviour Coram et al. (2003), reduced audit quality acts (Kasigwa et al., 2013, Coram et al., 2000, Herrbach, 2001) and irregular auditing (e.g., Donnelly et al., 2003, Herrbach, 2001, Khan et al., 2013, Paino et al., 2011, Yuen et al., 2013). Passive leaders, however, might choose to respond only after problems have become serious and may avoid making decisions (Avolio and Bass, 2004, Frooman et al., 2012, Horwitz et al., 2008).

In our case, a paradox lens enables us to explore the backstage of audit work and how audit teams respond to the recurring contradictory pressures and opposing requirements encountered in a government audit setting. The focus is on the impact of team diversity in respect of issues such as educational background, professional development, employment history, and levels of supervision on behaviour that affects the overall audit quality.

\section{Research Method}

Our research utilised a case study approach. Several methods of data collection were used, such as interviews, observation, and document analysis (Lewis, 2000). We explored in depth the activities and events relating to one or more individuals in a particular context (Cameron and Quinn, 1988). Following (Malone and Roberts, 1996), we use a systematic observation schedule to ensure that each participant's behaviour and applicable control systems could be identified and recorded effectively but there was also flexibility in the plan so that the schedule could be adjusted to fit changing circumstances and opportunities as they arose (Alderman and Deitrick, 1982).

\subsection{Obtaining Access}

We initially contacted two internal and one external government audit organisations in Indonesia with a view to gaining access. In view of the sensitivity of the research topic, we explained that we would emphasise the anonymity and confidentiality of the participants 
and also the audit organisations. Of the three audit organisations in Indonesia ${ }^{1}$, one agreed to grant us full access, to conduct interviews, focus group discussions, and access to relevant internal documents. After an initial request to observe a total of eight audit teams, we were able to observe five teams. We made the necessary arrangements with the heads of the audit units in order to schedule our attachment to the teams and to facilitate data collection.

\subsection{Data Collection}

\section{-------- Insert Table 1 here --------}

Observations were conducted by travelling together with the auditors during the audit field engagement period. We were able to observe and make notes regarding their activities and also to access and analyse their working papers. We attempted to act as much as possible as a passive observer in order that we might minimise our impact on them. We observed 30 auditors across five audit teams who were carrying out audit fieldwork at client sites. Total observation time exceeded 180 hours, and included approximately 40 hours of interim ${ }^{2}$ audit, and 150 hours during substantive ${ }^{3}$ audit, as shown in Table 1.

\section{Insert Table 2 here}

We travelled with each audit team throughout their engagement. Formal interviews (see Table 2) and informal conversations were held with the members of audit teams (in auditor rooms, restaurants, vehicles, etc.). We had access to working papers and other documents related to the engagement. We were able to watch out for any sign of fatigue, boredom, difficulty, worry, upset and other emotions. The main challenge during the observation was to maintain the trust of the team members. We used observational field notes (Marshall and Rossman, 2010), consisting of descriptive notes (profile of participants or team, a description of the physical setting and accounts of particular events or activities), reflective notes (the researcher's personal thoughts such as impressions, feelings, ideas and prejudices) and demographic information (time, place and date where the observation was conducted).

We sought to do this by emphasising that their anonymity would be preserved and confidentiality maintained. We sought a balance of engagement without being too obtrusive. As a passive approach was adopted, notes were not taken while observations were taking place on site, in order to reduce any possible impression of monitoring. We focussed on 'essential aims and partitioned off the setting by observing the group/informants during specific times, in certain location, and during the course of particular events and/or routines' (Berg, 2001).

\section{Insert Table 3 here}

Semi-structured interviews were conducted with 50 respondents (refer to Tables 2 and 3). An interview protocol or interview guide was developed for this research. Interviews

\footnotetext{
${ }^{1}$ We contacted three government audit bodies who have responsibility for the internal and external inspection of both central and regional/local government, state owned enterprises, all ministries, political parties' budgets, activities and programmes under the special order or assignment of the president

2 The interim audit, used mainly to assess and test the auditee's internal control for developing strategies for substantive tests in the form of an audit programme.

3 Substantive testing is part of the financial statement audit phase that is conducted to examine the financial statement accounts, transactions and activities/programme in order to test management assertions.
} 
were digitally recorded. Interviewees were selected from the hierarchical levels in the audit team: audit manager, supervisor, team leader and team member ${ }^{4}$. Interviews with observed auditors (see Table 3 ) were used to elaborate findings from the observations.

Interviews with those auditors not involved in the audit assignments (see Table 3) were carried out based on snowball sampling (Bryman, 2012). Some of non-auditor interviewees, such as a training centre manager, were selected following the recommendation of a previous interviewee in order to obtain further relevant information regarding a specific topic. We completed our data by identifying and collecting relevant documents, such as working papers, audit manuals, audit reports, etc.

\subsection{Data Analysis}

The data from all methods were analysed using qualitative thematic analysis. (Bryman, 2012) points out that thematic analysis is a method for identifying, analysing and reporting patterns (themes) within data. We analysed the profile of the team and the auditors observed, the description of the setting and the context of observations. We compared those data with our reflective observational notes including personal thoughts such as our impressions, feelings, ideas and prejudices (where we could identify them) about the actual events and activities. We also corroborated the analysis of our data from interviews and observations with our review of documents (working papers, audit manuals, etc.) in order to verify meaning and relevancy (Ritchie et al., 2003 p.229).

Recurring issues were identified, indexed and triangulated to link various categories and to develop themes. This process required extreme care in order to ensure the data were synthesised into themes without losing content, context and the language in which it was expressed. We labelled the themes and subthemes to link them to a relevant particular section of the data in the observational field notes.

The last phase was summarising or synthesising the key themes and then constructing a thematic chart/matrix. The main themes resulting from our analysis include: 'audit team diversity'; issues in team coordination'; 'lack of team cohesion'; and 'threats to audit quality'. We used Smith and Tracey (2016) processual assumption of paradox theory as a reference to identify the source, the emergence and the responses to paradox, as presented in Figure 1.

Finally, we employed respondent validation by presenting our analysis to $I A B$ in October 2017. We received supportive feedback to strengthen our analysis. IAB used our findings to review standard of audit engagement and structure a new training programme for junior auditors in order to improve engagement practices and audit quality. This represents "a process whereby a researcher provides the people on whom he or she has conducted research with an account of his or her findings" (Ahrens and Chapman, 2006, Malsch et al., 2013, Pentland, 1993). It is intended to seek corroboration and confirmation and to ensure the findings are congruent with the view of those on whom the research was conducted.

\section{Sources of Paradox in Government Audit Team Engagements}

$I A B$ is one of the three audit bodies in Indonesia. IAB conducts financial, performance and special purpose external audits of state, regional or local governments and also stateowned and local government-owned enterprises and other government entities. Financial audit is regulated by national law and includes independent assurances on budgets, balance

\footnotetext{
${ }^{4}$ A supervisor deals with the monitoring and evaluation of the audit, ensuring the audit takes place in accordance with the audit programme. The audit manager (also known as the auditor in charge) acts as a manager with responsibility for quality control across the whole audit process and its compliance with the auditing standards.
} 
sheets, cash flow statements and notes to financial statements. Performance audit, also referred to as a value-for-money audit, is intended to assess the effectiveness, efficiency and economy of the auditee. Special purpose audits deal with specific areas outside the scope of financial statements and performance including, for example, environmental, tax-related or investigative audits.

The IAB has faced a shortage of audit staff across all areas of operation for several years. A government report in 2012 suggested that the IAB, with 3,963 active auditors, is obliged to carry out financial audit in more than 3,000 entities. A local government financial statements' audit normally consists of six auditors including one audit manager, one supervisor, one team leader, and three more junior auditors. In the case of auditing a ministry/governmental institution, the number of auditors can require up to twenty auditors, divided into several sub teams, each with its own leader. IAO offices in a specific region usually employ 50 auditors to conduct 25 audits within 3 months. Staff shortages create time pressure for the audit teams. Despite the detailed audit expertise requirements defined by the National Audit standards, the IAB appears to have insufficient resources to form teams with an appropriate mix of individual expertise, skills, and competence.

Resource scarcity at the IAB results, at least in part, from insufficient funding which constrains the IAB's ability to both manage its budget and recruit sufficient trained staff. Such resource shortages mean that the extensive statutory audit requirements cannot be fulfilled. IAB has insufficient funding to recruit experience auditors. The high number of audits leaves a limited time to train and develop the leadership skills of junior auditors. As a result, the number of auditors capable of leading or supervising teams is very limited. There is a tendency for the IAB to prematurely promote inexperienced individuals to team leader positions. This can reduce team effectiveness, as a result of inadequate/weak leadership (Hackman and Wageman, 2005, Pratt and Jiambalvo, 1981, Burke et al., 2006). A senior supervisor expressed his view of this matter:

In some units, the auditors were prematurely promoted to a higher level. The auditor who has not had enough experience has been pushed to do a higher role. I mean maybe he is not ready to be a team leader. (Auditor 14, Supervisor, Interview

As a result, there are times when team leaders appear to be ineffective at keeping work on track or meeting deadlines. In other instances team leaders may fail to react as conflicts emerge, eventually leading to more serious problems within the team. The lack of leadership capabilities may trigger conflict and resistance from team members, rather than offering a conduit for resolving problems.

The IAB also struggles with its annual planning activities. The scheduling of auditor assignments over the year has often proven to be ineffective. It is common practice to immediately assign a newly appointed auditor to an engagement without giving them time to learn about their new environment and the knowledge required. Auditors are often allocated/reallocated and transferred from one team to another, as discussed by a team leader below.

We don't have enough planning. An auditor could be told [he/she is to be] ... included in a team just before an engagement [often only a couple of days prior]. Although the audit programme generally does not significantly change from the previous engagement, that doesn't mean we [the team] doesn't need time to understand the context (Auditor 10, Team Leader, Interview). 
Ideally, the audit team membership should remain fixed over the complete audit period (including in the course of preliminary and substantive tests), but lack of resources and inadequate planning result in frequent team changes that lead to poor teamwork. Detailed audit plans are left to the team, rather than managed at a higher level.

Sometimes we just know we are plotted in an engagement just one or two days before the fieldwork starts. Even just a few hours before the departure to the audit entities the team members can be changed. It is so difficult for the auditor because he has to understand the audit environment, auditee's business process, and the audit procedures before the fieldwork (Auditor 12, Team Member, Interview).

The lack of higher level planning means individual auditors are regularly and unpredictably moved to new assignments. This increases the pressure on individuals to learn new things and rapidly assimilate into new teams. One impact of a lack of planning is that the balance between various capabilities, expertise and specialisations is often overlooked when assembling an audit team. This combination of inadequate resourcing and imbalance of team skills and experience affects the behaviour of individual team members as well as overall team effectiveness. This results in the emergence of the paradox of team diversity, which represents recurring contradiction between team heterogeneity/diversity and the ability to achieve team cohesion. This is the focus of the next section.

\section{Team Diversity and the Emergence of Paradox}

The following analysis describes the emergence of the paradox of team diversity. The $I A B$ stimulates distinctions and embeds persistent contradiction between the need for team diversity and team cohesion in the audit process. In addition, the scarcity of resources creates various problems and challenges, including planning, control and team interrelationships. Audit teams at IAB need to include auditors with varying backgrounds, knowledge, expertise and proficiency. However, the mix of expertise is not always carefully considered due to the limited number of auditors and the high number of audits. This results in unplanned or poorly controlled heterogeneity of team members' knowledge and skills. This can affect the coherence of team activity, as represented in Figure 2 below.

Figure 2 Paradox of Team Diversity

\begin{tabular}{l|l|l|}
\hline $\begin{array}{l}\text { An audit team needs a mix } \\
\text { of auditors with various } \\
\text { knowledge, skills, } \\
\text { proficiency, and } \\
\text { backgrounds that may have } \\
\text { benefits in a complex audit } \\
\text { environment that needs a } \\
\text { variety of expertise. }\end{array}$ & $\begin{array}{l}\text { Heterogeneity } \\
\text { cohesion to achieve team's } \\
\text { (rather than individual's) } \\
\text { agreed goals. Individuals } \\
\text { should act in accordance } \\
\text { with team's objectives. }\end{array}$ \\
\hline
\end{tabular}

The paradox of team diversity produces a persistent contradiction between heterogeneity and cohesion. These two important aspects in team work appear logical when in isolation, but inconsistent, when juxtaposed (Lewis, 2000, Smith and Lewis, 2011). Heterogeneity may have benefits in a complex audit environment that needs a variety of expertise. On the other hand, it may undermine collaboration among team members because some individuals may act independently and maintain too much distance from other team members. 
In my division, there are some auditors who do not come from an accounting background. As an accountant, according to my knowledge, an audit is the reverse of the accounting process... but they do not have that kind of thinking. They do not fully understand what the process and the documents are, just collecting the documents, and sometimes may not be able to review them in a comprehensive way (Auditor 30, Team Member, Interview).

For some auditors, this variation [team membership] may improve their knowledge... just like me, now I know some new things... but sometimes they are forced to understand something outside their expertise... they may share with each other but it may slow down the pace of the audit (Auditor 31, Team Member, Interview).

During the observations of Team B, we found that instead of being collaborative, some auditors seemed to focus too much on their own expertise. Some of the team members argued that a financial audit needs only to be carried out by those auditors with the relevant accounting educational background. Auditors without an accounting background were included in the team to provide the additional skills required, but some of their colleagues felt their accounting knowledge was inadequate. This impacted on the cohesion of the team as the following comment indicates.

When doing a financial statement audit sometimes our team are struggling because the auditors may come from too many different backgrounds (Auditor 30, Team Leader, Interview).

It proved difficult for this team to develop an agreed plan. The team members had conflicting views in considering the level of materiality and risk. They also had difficulties to achieve an agreed approach in selecting evidence. Auditors need to make an effort to share their knowledge. This may, simultaneously, slow down the pace of the audit creating another potential contradiction.

Sharing seems to be sporadic in Team D. Individual auditors were observed to discuss progress and work practices with colleagues of similar background. Some of them may be reluctant to help others because they believe that may have too different a point of view. One auditor explained: 
Three of us in the team are not familiar with this audit (they have just been moved from other units). So we can't help each other (Auditor 4, Team Member, Interview).

In Team E, Auditors in the field often reported that they had not known each other before the first day of the audit fieldwork. Interviewees argued that they might need some time to get to know each other through regular interaction. They went on to suggest that coming to share the team goals must be built over time.

If we talk about individual perspectives, every person will be different, type $X$ and $Y$ person. One may be self-motivated while others may not (Auditor 32, Team Member, Interview).

Individual professional judgement may sometimes conflict with group decisions. This can happen where team members with various academic backgrounds and areas of expertise reach different judgements. Even though all of them have undergone the relevant training and certification to acquire the required accounting and auditing skills this is only part of what may affect professional judgement. Psychological and interpersonal aspects may also influence decision making and team cohesion.

There are many instances where individuals within a team cannot cooperate with other team members. They tend to work on their own without any discussions or consultations with others. They do not always appreciate the importance of team cohesion among team members, team leader and supervisor to achieve the objective of an audit engagement. (Auditor 18, Team Leader, Interview).

Problems may emerge where team members do not conform to the team's accepted behaviour, which can undermine team cohesion. The main tension arises from the need for auditors with various backgrounds, knowledge and skills to maintain teamwork and team cohesion within the variations across individual characteristics, values, and motivation. The paradox escalates as many inexperience team leaders who are prematurely promoted lack the capability to lead the teams. Audit teams cannot avoid and resolve paradoxical situations. The persistence of paradoxes within audit engagement work requires audit teams to engage in ongoing processual responses in their efforts to adjust and work effectively in diverse and complex situations (Smith and Tracey, 2016). These issues are discussed in the following section.

\section{Cascading Responses to Paradox of Team Diversity}

This section provides evidence and discussion of what we conceptualise as the cascading responses to the paradoxes that are created by team diversity. While we describe some RAQP arising within each team, some of these instances are much more concerning than others. Nevertheless our observations of the five audit teams indicate that contradictions between diversity and cohesion in individual audit assignments may persist long enough to become disruptive. This can provoke iterative or cascading responses at both the team leader and team member level, as shown in Figure 3 below. This is where we identify the actions of team leaders and other team members as influencing the behaviour of others. The actions we identify create an environment in which RAQP is best seen as being an inevitable and perhaps acceptable response to paradoxical pressures, which create environments where insufficient time or resources impact the audit assignments in a systemic way. 
Figure 3 Evidence of Cascading Responses to Paradox of Team Diversity

\begin{tabular}{|c|c|c|c|c|}
\hline Team & $\begin{array}{l}\text { Context of } \\
\text { observation }\end{array}$ & Evidence of Superficial audit supervision & & $\begin{array}{c}\text { Evidence of Non tested sample \& premature } \\
\text { sign-off }\end{array}$ \\
\hline A & $\begin{array}{l}\text { Audit of a } \\
\text { provincial } \\
\text { health } \\
\text { service } \\
\text { provider }\end{array}$ & $\begin{array}{l}\text { The team leader was away from the team } \\
\text { for much of the engagement. The audit } \\
\text { engagement was lacking coordination and } \\
\text { clarity of work tasks. }\end{array}$ & $\Rightarrow$ & $\begin{array}{l}\text { The team members undertake a minimum } \\
\text { verification on client' stock without proper } \\
\text { planning. They checked a sample well below } \\
\text { what was required. They conducted the } \\
\text { procedure in a very short time with } \\
\text { insufficient depth. }\end{array}$ \\
\hline $\mathbf{B}$ & $\begin{array}{l}\text { Audit of a } \\
\text { regional } \\
\text { province }\end{array}$ & $\begin{array}{l}\text { The team leader seemed to lack } \\
\text { confidence in his knowledge of recent } \\
\text { changes of regulation relevant to the } \\
\text { auditee context. She/he did visit the team, } \\
\text { but conducted a very light review. Largely } \\
\text { leaving the team without supervision. } \\
\text { Individual audit steps and procedures } \\
\text { were not managed. A visit was made to } \\
\text { the audit team at the end of the } \\
\text { fieldwork/assignment and a very light } \\
\text { check on findings conducted. }\end{array}$ & $\Rightarrow$ & $\begin{array}{l}\text { Team members were in charge of one of the } \\
\text { province' social donation accounts. They did } \\
\text { not follow the required sample selection and } \\
\text { procedure for such a review. They argued } \\
\text { that it would be difficult to follow the } \\
\text { requirements and procedures. They did not } \\
\text { take further examination on any suspicious } \\
\text { items and decided to conclude the review } \\
\text { without further checks. }\end{array}$ \\
\hline $\bar{C}$ & $\begin{array}{l}\text { Audit of a } \\
\text { municipality }\end{array}$ & $\begin{array}{l}\text { Team leader admitted that the team did } \\
\text { not complete the overall review. There are } \\
\text { no signatures of the team leader and audit } \\
\text { manager in the working papers, although } \\
\text { they visited the team during the } \\
\text { preliminary fieldwork. The team leader } \\
\text { asked about general problems without } \\
\text { looking at the documents in detail. }\end{array}$ & $\Rightarrow$ & $\begin{array}{l}\text { Team members did not complete an overall } \\
\text { review. They argue that it was difficulties to } \\
\text { collect the entire sample, because the } \\
\text { volume of evidence was very high. They only } \\
\text { selected the evidence representing the } \\
\text { largest budget centre and the worst } \\
\text { documentation. In the end, they conclude } \\
\text { their findings without including valid } \\
\text { evidence. }\end{array}$ \\
\hline$\overline{\mathbf{D}}$ & $\begin{array}{l}\text { Audit of a } \\
\text { state-own } \\
\text { enterprise }\end{array}$ & $\begin{array}{l}\text { Team leader stated that she was } \\
\text { appointed to lead the team although she } \\
\text { has no experience on the auditee's } \\
\text { context and this type of audit. Only one } \\
\text { auditor in her team has experience and } \\
\text { has audited in the same context before. }\end{array}$ & $\Rightarrow$ & $\begin{array}{l}\text { Most of the team members are not familiar } \\
\text { with auditing the government subsidy } \\
\text { programme administered by the client. The } \\
\text { work exhibits a lack of planning and proper } \\
\text { procedure. Team members appeared to take } \\
\text { the review too lightly. }\end{array}$ \\
\hline $\mathbf{E}$ & $\begin{array}{l}\text { Audit at a } \\
\text { national } \\
\text { custom } \\
\text { office }\end{array}$ & $\begin{array}{l}\text { The team leader conducted a superficial } \\
\text { review. He/she sometimes asks how } \\
\text { things have been done, but only in general } \\
\text { terms. The working papers, other } \\
\text { documents and audit procedures are not } \\
\text { checked. The team leader does not feel } \\
\text { that the standardized checks are relevant. } \\
\text { He/she believes there are many } \\
\text { unnecessary steps, which waste time. }\end{array}$ & $\Rightarrow$ & $\begin{array}{l}\text { Team members have conducted a very light } \\
\text { review on the selected evidence. A sample } \\
\text { was selected based on convenience. } \\
\text { Shortcuts to complete the review were } \\
\text { clearly taken. Team members to simply } \\
\text { follow and avoid what the team leader } \\
\text { believes are unnecessary steps. }\end{array}$ \\
\hline
\end{tabular}

Some team leaders engage in practices that downplay their responsibility to supervise, monitor and manage tensions in the team. This cascades down and provides discretionary space for team members to downscale the audit process by avoiding legitimate audit tasks. In these circumstances the team leaders withdraw themselves somewhat from the team by performing superficial supervision (see Figure 3 above). We posit that superficial supervision occurs as a relatively inexperienced team leader chooses to withdraw themselves from the sometimes, necessary, intensive monitoring of the team. This practice may be perceived to shield their lack of capability from the team. Superficial audit supervision is a form of RAQP conducted by team leaders. 
The supervisor does not carry out supervisory control function properly. When we seek for advice sometimes they just tell us to do what we think we should do (Auditor 33, Team Member, Interview).

Managing team diversity to achieve team cohesion becomes even more difficult to achieve when individuals who are inexperienced and lack expertise are prematurely promoted. Some inexperienced team leaders do not proactively monitor the team's work on a daily basis, waiting instead for weekly reports, and rarely communicate directly with their team.

I had a team leader who didn't direct us at all. When I asked what to do next, he just said just do what you need to do. After [the client] entry briefing he was always busy... I felt a bit desperate. (Auditor 33, Team Member, Interview).

We observed team leader practices that focused too much on resolving issues as they arose, rather than detailed planning and monitoring. One auditor gives his view:

'They did not check our working papers... some supervisors just asked for our main findings. They very seldom asked about the audit procedures or whether we had difficulties in performing them. At best they asked whether the data were easy to get or not.... (Auditor 23, Male, Team Member, Interview)

In these cases the team leaders rarely checked all completed procedures and failed to review the adequacy of evidence in individual's working papers. Such team leaders largely rely for assurance on general discussions with the team without looking at the written reports and the documented evidence attached to the working papers.

When a team leader fails to provide adequate oversight or manage conflict within a team, there is an opportunity for auditors to engage in downscaling the audit process by engaging in two different types of RAQP: reducing or non-testing items in a sample and premature sign-off (see Figure 3). Team members engage in these types of RAQP, to maintain an acceptable work environment and manage work related anxiety (Herrbach, 2005, Sweeney and Pierce, 2011, Sweeney and Pierce, 2006). We observed how a team member resorted to reducing/not testing the relevant evidence.

So we reduce [for test] the amount of samples selected and there are some client's explanations that we still have doubt about but we just accept them (without further examination) (Auditor 5, Team Member, Interview).

Team A (see Figure 3) was assigned to test an assertion by management of the existence of certain medical equipment. According to the audit procedure on capital expenditure testing, the team should 'conduct a physical examination of the existence of the asset resulted from the spending of capital expenditure'. The auditor designated to carry out this check needed to conduct a stock examination on that same day, but left without doing so. This exchange is shown below (and is followed by other brief vignettes):

Auditor A: I think the auditee has conducted a proper purchase procedure...

Auditor B: Are you sure? I am not convinced

Auditor A: Actually, I am not really convinced. I just get the confirmation from someone in charge.

Auditor B: But, the procedure says that we need to conduct physical examination instead of just relying on his reports. 
Auditor A: I think it is enough...we don't need to do anything else

Some members of the team had been reviewing purchase order documents for the assets in question since the morning, but then the other auditor tells them that he has decided not to perform the physical test. He states that the auditee has conducted proper purchase procedures and there has been a report from the employee in charge of the purchase stating that the assets have been received.

Only the auditor and God know whether he really has tested all the items in the sample or not. We really don't know if they left the items because, for example, he couldn't get the documents or because of other reasons. (Auditor 1, Team Leader/Supervisor, Interview)

The supervisor above decides to ignore the need to check whether or not the auditor has adequately confirmed the asset's existence. Arguably, this may be difficult because auditors are not required to keep the tested documents in their working papers, but the example illustrates how RAQP can cascade down. Ineffective supervision is compounded and mirrored in the failure to complete a simple asset test.

In Team B, some auditors stopped at a point at which they suspected irregularities, without either extending their efforts or seeking alternative instructions. The auditors claimed they were reluctant to revise procedures, as they would simply be reported to the team leader/supervisor who had been failing to monitor the audit engagement effectively. In other words, their additional work would go unrecognized. Reviews of working papers during the final stage of the audit reveal that team members engaged in premature sign-off and reluctant to challenge the outcome, the inexperienced team leader signed and approved the completion of the audit.

On a different audit, two auditors of Team $\mathrm{C}$ visited a construction site accompanied by two client representatives. They merely had a brief chat and took some photos of the building without even looking at the documents they had brought or matching them against the physical evidence in the field. One of the team members stated that:

When examining the cupboards procurement, I was required to check the existence of them, and check whether the specifications match the available documents. They matched I said ... [to complete/sign-off the procedure], although I was pretty sure there seemed to be something wrong with them. (Auditor 11, Team Member, Interview)

Following conversations held with one of the auditors during the examination, it seemed they did not have the requisite knowledge to conduct this examination and had just been moved from another team. A lack of communication and cohesion with other members of the team made them reluctant to request help from a more experienced individual.

The above examples illustrate the scope for inadequate testing and premature signoff that breaches accepted standards of audit quality. We therefore conclude that in response to time pressures, unresolved tensions, failings in supervision and a lack of team cohesion, team members are able to engage in RAQP. As such, organizational characteristics facilitate the emergence of paradox of team diversity which stimulate the cascading down of poor audit practice from team leader to the team member level. We would reiterate our comment from the start of this section that the paradoxes we identify are specific to the context we have investigated but would likely be representative of paradoxes found 
elsewhere in audit team work. Paradox is inherent in much organizational team work and audit is no exception.

\section{Discussion and conclusion}

Much conventional academic research on auditing is limited to applications using experimental as opposed to real world settings. Power (2003) argues that 'very little is known about auditing in practical, as opposed to experimental, settings'. The research discussed in this paper seeks to respond to Power's call by providing findings from a real world setting that contribute to enhance our understanding of auditors' behaviour through case study and observation. Our research aim was to explore the response of audit teams to the recurring contradictory requirements encountered in the complex environment of government audit practice. Our findings offered insights on concerns around inadequate resourcing and planning that tend to stimulate paradoxes in audit engagement work. Our research has sought to examine the backstage of government audit work and reveal aspects of resourcing and planning and especially team diversity that give rise to complex paradoxes in audit work. We identify how these paradoxical conditions promote RAQP which we interpret as cascading through the audit team.

\subsection{Micro sociological aspects of audit team practices}

Our research has explored contradictory requirements in audit assignments from a sociological perspective as we seek a more substantial understanding of the 'the backstage of audit work' (Bamber et al. (1998). Despite the unique and critical role of government audit institutions in society, empirical attempts to consider the micro sociological aspect of audit team processes have remained limited (Gendron et al., 2001, Power, 1999, Gendron et al., 2007, Radcliffe, 1997, Funnell, 2004, Funnell, 1998, Skærbæk, 2009). We provide a deeper understanding of the audit engagement process (Solomon and Trotman, 2003) by revealing auditor behaviour, that cannot effectively be explored in other methods such as survey questionnaire or experimental research (Herrbach, 2002).

We argue that audit scholarship needs to take into account internal elements and dynamic effects in the audit process, especially in the work of the audit team (Gittell, 2004). Taking a micro sociological perspective of team processes extends our understanding of the internal and external infrastructure in the audit process (Smith and Berg, 1987). Our evidence confirms the value of ensuring that audit research should take account of the complexity and resourcing challenges in government audit infrastructure (Notgrass et al., 2013, Vera-Munoz et al., 2006, Bamber et al., 1998).

The empirical evidence gathered in this research supports the existence of opposing demands as audit teams work across multiple knowledge-bases (Carron et al., 1998, Gammage et al., 2001, Smith and Berg, 1987) and face the challenge of heterogeneity within the team (Smith and Berg, 1987). We demonstrate the challenge of a team's ability to work with a lack of common values and inexperienced team leaders, and show that audit teams often struggle to manage opposing demands within complex interdependent audit tasks, roles, capabilities and knowledge.

Some of these paradoxes arise from the need to ensure plurality in team members' educational and technical backgrounds whilst still aiming to nurture cohesion. The five audit teams we followed displayed poor coordination and cohesion among team members but also in relations with the team leader. Poor coordination can result in unbalanced workloads, tough deadlines and excessive workloads. Some supervisors and team leaders with limited experience (possibly due to premature promotion) were seen to struggle to coordinate work effectively (Notgrass et al., 2013). 
Diversity can produce positive effects but these may be accompanied by lower levels of coordination due to the pursuit of personal self-interest, conflict between members, and poor communication (Srikanth et al., 2016, Jehn, 1995, Amason et al., 1995). It can then be a challenging task to achieve shared team values in the face of these conflicting motivations, personal values and characteristics. Paradoxes within the audit team may emerge to reinforce organizational contradictions and reveal organisational problems such as staff shortages and inadequate planning.

\subsection{RAQP as cascading responses to paradox in audit team}

Our analysis provides a different and more intensive approach to studying RAQP (Coram et al., 2008). We expand the discussion on auditor's responses to conflicts (Sweeney and Pierce, 2011), in which auditors employ defence mechanisms (Sweeney and Pierce, 2006) or a coping mechanism (Herrbach, 2005). Our contribution reveals two types of coping strategies adopted by team leaders and auditors. We identified RAQP practices by both team leaders and team members represent the cascading responses to paradox in audit team.

We argue that RAQP, in the complex environment of government auditing, are cascade down from team leader to team member. Team leaders' superficial supervision opens up an opportunity for audit team members to restrict their audit tasks by reducing sample size, which in turn allows premature sign-off. We argue that inadequate supervision is one of the factors driving RAQP (Rhode, 1978, Alderman and Deitrick, 1982, Otley and Pierce, 1996). But our focus here is different to the existing literature in revealing the complementarity of inexperience among audit team leaders and team members. We show that auditors adjust their practices and, in the extreme, engage in RAQP to control the opposing demands they face in the audit process. RAQP becomes a dynamic process that auditors use to manage the paradoxes they face (Srikanth et al., 2016). RAQP also becomes a response to ineffective or poor leadership (Srikanth et al., 2016). In our case, RAQP becomes an attractive short-term solution for addressing a paradox in audit team composition (Pentland, 1993).

Our findings suggest that it is possible to overcome an implication in the literature that informants may be unwilling to reveal their true behaviours in responding to RAQP research (Rhode, 1978, Alderman and Deitrick, 1982, Otley and Pierce, 1996, Herrbach, 2001). Our micro level case study would suggest otherwise and adds new insights to the existing RAQP research that relies on self-reported surveys, questionnaires, experiments and other documentary evidence using quantified measurement and variables (Herrbach, 2001). The existing studies tend to explore RAQP as a homogeneous group of practices and aggregated auditors' responses (Coram et al., 2008). Our paper provides a new insight on how RAQP is a complex and diverse part of team practice. Some of the RAQP we describe as committed by senior auditors/team leader provides discretionary space for similar practices by team members.

\subsection{Conclusion}

While team diversity is often valued in audit work, this paper provides evidence that it also poses problems that result in potentially poorly coordinated and incoherent teamwork. Our research reveals that organisational problems can exacerbate these contradictions. The problems include under-resourcing and inadequate training, which can lead to ineffective audit team selection processes and excessive transfer of individual auditors between teams. Some research has suggested a lack of commitment among national institutes in providing effective oversight function of the audit process (Humphrey, 2008). Humphrey attributes this to under resourcing and a consequent lack of capacity to innovate in the advancement of auditing knowledge. A lack of training is also presented in 
our research findings. Senior auditors have important roles, which are not restricted to technical knowledge but extend to the effective management of engagement teams.

Our empirical analysis indicated that the paradox of team diversity emerged in a context of constrained resourcing that leads to RAQP. Evidence from our interactions with senior managers within IAB suggested that these contradictory pressures are persistent and difficult to resolve. Consequently, supervisors and team members simultaneously engaged in interrelated RAQP actions. Supervisors performed superficial supervision due to poor training. These failings in providing leadership to the team and monitoring team work, gave discretion for auditors to engage in actions including the reduction of sampled items and premature sign-off. We describe this as resulting in cascading RAQP.

According to Gendron and Bédard (2001), auditing research is useful to a particular subset of auditing research stakeholders, i.e. to auditors and members of the auditing profession. We hope that our study of everyday audit practice will prove helpful to government and private sector audit organisations, professional bodies and government audit standard setters (Sikka et al., 1998, Porter, 1993, Power, 2000). Our research provides a different perspective on the dynamics and paradoxes within the audit process, and perhaps greater insight into the occurrence of RAQP. Over time, a deeper understanding of what factors trigger RAQP will serve to enhance audit quality across all sectors of the economy.

\section{References}

AHRENS, T. \& CHAPMAN, C. S. 2006. Doing qualitative field research in management accounting: Positioning data to contribute to theory. Accounting, Organizations and Society, 31, 819-841.

AICPA 1978. The Commision on Auditors' Responsibilities: Report, Conclusions, and Recommendations. New York: The Commision on Auditors' Responsibilities American Institute of Certified Public Accountants.

ALDERMAN, C. W. \& DEITRICK, J. W. 1982. Auditors Perceptions of Time Budget Pressures and Premature Sign Offs: A Replication and Extension. Auditing: A Journal of Practice \& Theory, 1, 54-68.

AMASON, A., HOCHWARTER, W., THOMPSON, K. \& HARRISION, A. 1995. Conflict: An important dimension in successful management teams. Organizational Dynamics, 24, 25-35.

ARNABOLDI, M., LAPSLEY, I. \& STECCOLINI, I. 2015. Performance management in the public sector: The ultimate challenge. Financial Accountability \& Management, 31, 1-22.

AVOLIO, B. J. \& BASS, B. M. 2004. Multifactor Leadership Questionnarie: Manual \& Review Copy, Mind Garden.

BAMBER, E. M. 1983. Expert Judgment in the Audit Team: A Source Reliability Approach. Journal of Accounting Research, 21, 396-412.

BAMBER, E. M., HILL, M. C. \& WATSON, R. T. 1998. Audit Group and Group Support Systems: A Framework and Propositions for Future Research. Journal of Information Systems, 12, 45-73.

BAMBER, E. M. \& RAMSAY, R. J. 2000. The Effects of Specialization in Audit Workpaper Review on Review Efficiency and Reviewers' Confidence. Auditing: A Journal of Practice \& Theory, 19, 147-157.

BEAL, D., COHEN, R., BURKE, M. \& MCLENDON, C. 2003. Cohesion and performance in groups: A meta-analytic clarification of construct relations. Journal of Applied Psychology, 88, 989-1004. 
BEATTIE, V. \& FEARNLEY, S. 1998. Auditor changes and tendering: UK interview evidence. Accounting, Auditing \& Accountability Journal, 11, 72-98.

BERG, B. L. 2001. Qualitative Research Methods For The Social Sciences, MA, USA, A Pearson Education Company.

BONNER, S. E. 1994. A model of the effects of audit task complexity. Accounting, Organizations and Society, 19, 213-234.

BRACCI, E., HUMPHREY, C., MOLL, J. \& STECCOLINI, I. 2015. Public sector accounting, accountability and austerity: more than balancing the books? Accounting, Auditing \& Accountability Journal, 28, 878-908.

BRYMAN, A. 2012. Social Research Methods, OUP Oxford.

BURKE, C. S., STAGL, K. C., KLEIN, C., GOODWIN, G. F., SALAS, E. \& HALPIN, S. M. 2006. What type of leadership behaviors are functional in teams? A meta-analysis. The leadership quarterly, 17, 288-307.

CAMERON, K. S. \& QUINN, R. E. 1988. Paradox and transformation: Toward a theory of change in organization and management. In: QUIN, R. E. \& CAMERON, K. S. (eds.) Organizational paradox and transformation. Cambridge, MA: Ballinger.

CARRON, A. V., BRAWLEY, L. R. \& WIDMEYER, W. N. 1998. The measurement of cohesiveness in sport groups. In: DUDA, J. (ed.) Advances in sport and exercise psychology measurement. Morgantownm, WV: FIT Technologies.

CORAM, P., GLAVOVIC, A., NG, J. \& WOODLIFF, D. R. 2008. The moral intensity of reduced audit quality acts. Auditing: A Journal of Practice \& Theory, 27, 127-149.

CORAM, P., NG, J. \& WOODLIFF, D. 2000. The Effects of Time Budget Pressure and Risk of Error in Auditor Performance. AAAANZ.

CORAM, P., NG, J. \& WOODLIFF, D. 2003. A Survey of Time Budget Pressure and Reduced Audit Quality among Australian Auditors. Australian Accounting Review, 13, 38-44.

CURTIS, E. \& TURLEY, S. 2007. The business risk audit-A longitudinal case study of an audit engagement. Accounting, Organizations and Society, 32, 439-461.

DEANGELO, L. E. 1981. Auditor size and audit quality. Journal of accounting and economics, 3, 183-199.

DONNELLY, D. P., QUIRIN, J. J. \& O'BRYAN, D. 2003. Auditor Acceptance of Dysfunctional Audit Behaviour: An Explanatory Model Using Auditors' Personal Characteristics. Behavioral Research in Accounting, 15, 87-110.

DOWLING, C. 2009. Appropriate audit support system use: The influence of auditor, audit team, and firm factors. The Accounting Review, 84, 771-810.

EISENHARDT, K. M. \& WESTCOTT, B. J. 1988. Paradoxical demands and the creation of excellence: The case of just-in-time manufacturing. In: QUINN, R. E. \& CAMERON, K. S. (eds.) Paradox and transiormation: Toward a theory of change in organization and management. Cambridge, MA: Ballinger.

ELLWOOD, S. \& NEWBERRY, S. 2007. Public sector accrual accounting: institutionalising neoliberal principles? Accounting, Auditing \& Accountability Journal, 20, 549-573.

FORD, I. D. \& BACKOFF, R. W. 1988. Organizational change in and out of dualities and paradox. . In: QUINN, R. E. \& CAMERON, K. S. (eds.) Paradox and transformation: Toward a theory of change in organization and management. Cambridge, MA:: Ballinger.

FRANCIS, J. R. 1994. Auditing, hermeneutics, and subjectivity. Accounting, Organizations and Society, 19, 235-269.

FROOMAN, J., MENDELSON, M. B. \& KEVIN MURPHY, J. 2012. Transformational and passive avoidant leadership as determinants of absenteeism. Leadership \& Organization Development Journal, 33, 447-463. 
FUNNELL, W. 1998. Executive coercion and state audit: A processual analysis of the responses of the Australian audit office to the dilemmas of efficiency auditing197884. Accounting, Auditing \& Accountability Journal, 11, 436-458.

FUNNELL, W. 2004. Victorian parsimony and the early champions of modern public sector audit. Accounting History, 9, 25-60.

GAMMAGE, K., CARRON, A. \& ESTABROOKS, P. 2001. Team cohesion and individual productivity: The influence of the norm for productivity and the identifiability of individual effort. . Small Group Research, 32, 3-18.

GENDRON, Y. \& BÉDARD, J. 2001. Academic auditing research: an exploratory investigation into its usefulness. Critical Perspectives on Accounting, 12, 339-368.

GENDRON, Y., COOPER, D. J. \& TOWNLEY, B. 2001. In the name of accountability-State auditing, independence and new public management. Accounting, Auditing \& Accountability Journal, 14, 278-310.

GENDRON, Y., COOPER, D. J. \& TOWNLEY, B. 2007. The construction of auditing expertise in measuring government performance. Accounting, organizations and society, 32, 101-129.

GIBBS, J. 2009. Dialectics in a global software team: Negotiating tensions across time, space, and culture. Human Relations, 62, 905-935.

GITTELL, J. H. 2004. Paradox of coordination and control. . California Management Review, 42, 101-117.

GRIFFITH, E. E., HAMMERSLEY, J. S. \& KADOUS, K. 2015. Audits of complex estimates as verification of management numbers: How institutional pressures shape practice. Contemporary Accounting Research, 32, 833-863.

GUÉNIN-PARACINI, H., MALSCH, B. \& PAILLÉ, A. M. 2014. Fear and risk in the audit process. Accounting, Organizations and Society, 39, 264-288.

HACKMAN, J. R. \& WAGEMAN, R. 2005. A theory of team coaching. Academy of Management Review, 30, 269-287.

HAMPDEN-TURNER, C. 1981. Maps of the mind, New York, Macmillan.

HERRBACH, O. 2001. Audit quality, auditor behaviour and the psychological contract. The European Accounting Review, 10, 787-802.

HERRBACH, O. 2002. (Maybe) not that dysfunctional after all: audit quality reduction behaviours and the evolution of auditing methods. European Accounting Association 25th Annual Congress. Copenhagen.

HERRBACH, O. 2005. The art of compromise? The individual and organisational legitimacy of "irregular auditing". Accounting, Auditing \& Accountability Journal, 18, 390-409.

HOOD, C. \& DIXON, R. 2015. A government that worked better and cost less?: Evaluating three decades of reform and change in UK central Government, OUP Oxford.

HORWITZ, I. B., HORWITZ, S. K., DARAM, P., BRANDT, M. L., BRUNICARDI, F. C. \& AWAD, S. S. 2008. Transformational, transactional, and passive-avoidant leadership characteristics of a surgical resident cohort: analysis using the multifactor leadership questionnaire and implications for improving surgical education curriculums. Journal of Surgical Research, 148, 49-59.

HUMPHREY, C., MILLER, P. \& SCAPENS, R. W. 1993. Accountability and accountable management in the UK public sector. Accounting, Auditing \& Accountability Journal, 6.

JARZABKOWSKI, P., LE, J. K. \& VAN DE VEN, A. H. 2013. Responding to competing strategic demands: How organizing, belonging, and performing paradoxes coevolve. Strategic Organization, 11, $245-280$.

JEHN, K. A. 1995. A multimethod examination of the benefits and detriments of intragroup conflict. Administrative Science Quarterly, 40, 256-282. 
KASIGWA, G., MUNENE, J. C., NTAYI, J. \& NKOTE, I. 2013. Reduced Audit Quality Behavior Among Auditors in Uganda. African Journal of Accounting, Economics, Finance and Banking Research, 9, 25-37.

KELLEY, T. \& MARGHEIM, L. 1990. The Impact of Time Budget Pressure, Personality, and Leadership Variables on Dysfunctional Auditor Behavior.pdf>. Auditing: A Journal of Practice \& Theory, 9, 21-42.

KHAN, S., PANATIK, S. A., SAAT, M. M. \& PERVEEN, H. 2013. Auditors' Behavioral Intention Towards Dysfunctional Audit Behaviour Applying Theory of Reasoned Action. Jurnal Teknologi, 64, 153-158.

LEWIS, M. W. 2000. Exploring Paradox: Toward A More Comprehensive Guide. Academy of Management Review, 25, 760-776.

MALONE, C. F. \& ROBERTS, R. W. 1996. Factors Associated with the Incidence of Reduced Audit Quality Behaviors. Auditing: A Journal of Practice \& Theory, 15, 49-64.

MALSCH, B. \& GUÉNIN-PARACINI, H. 2013. The moral potential of individualism and instrumental reason in accounting research. Critical Perspectives on Accounting, 24, 74-82.

MALSCH, B., GUENIN-PARACINI, H. \& TREMBLAY, M. 2013. Micro Games of Power in Auditing: Getting Comfortable with the Auditee. 36th Annual Congress European Accounting Association Doctoral Colloquium. Paris France.

MARSHALL, C. \& ROSSMAN, G. B. 2010. Designing Qualitative Research, SAGE Publications.

MCGRATH, J. E. 1982. Dilemmatics: The study of research choices and dilemmas, Sage Publications, Inc.

MCNAIR, C. J. 1991. Proper compromises: The management control dilemma in public accounting and its impact on auditor behaviour. Accounting, Organizations and Society, 16, 635-653.

MCPHAIL, K. 2004. An emotional response to the state of accounting education: developing accounting students' emotional intelligence. Critical Perspectives on Accounting, 15, 629-648.

MULLEN, B. \& COPPER, C. 1994. The relationship between group cohesiveness and performance: An integration. Psychological Bulletin, 115, 210-227.

MURNIGHAN, J. K. \& CONLON, D. E. 1991. The dynamics of intense work groups: A study of British string quartets. Administrative Science Quarterly, 36, 165-186.

NELSON, M. \& TAN, H.-T. 2005. Judgment and decision making research in auditing: A task, person, and interpersonal interaction perspective. Auditing: A Journal of Practice \& Theory, 24, 41-71.

NOTGRASS, D., CONNER, C. \& BELL III, T. J. 2013. Leading External Auditing Teams: The Correlation Between Leaders' Behaviors and Team Dynamics Of Cohesion and Conflict. International Journal of Business and Public Administration, Volume 10, Number 2, Fall, 10 Fall, 1-14.

OTLEY, D. T. \& PIERCE, B. J. 1996. Auditor time budget pressure: consequences and antecedents. Accounting, Auditing \& Accountability Journal, 9, 31-58.

PAINO, H., ISMAIL, Z. \& SMITH, M. 2011. Dysfunctional Audit Behaviour- The Effects of Employee Performance, Turnover Intentions and Locus of Control. Journal of Modern Accounting and Auditing, 7, 418-423.

PARKER, G. M. 1990. Team players and teamwork, San Francisco, Jossey-Bass.

PEECHER, M. E., SCHWARTZ, R. \& SOLOMON, I. 2007. It's all about audit quality: Perspectives on strategic-systems auditing. Accounting, Organizations and Society, 32, 463-485.

PENTLAND, B. T. 1993. Getting comfortable with the numbers: auditing and the microproduction of macro-order. Accounting, Organizations and Society, 18, 605-620. 
PICARD, C.-F., DUROCHER, S. \& GENDRON, Y. 2014. From meticulous professionals to superheroes of the business world: A historical portrait of a cultural change in the field of accountancy. Accounting, Auditing \& Accountability Journal, 27, 73-118.

PIERCE, B. \& SWEENEY, B. 2004. Cost-quality conflict in audit firms: an empirical investigation. European Accounting Review, 13, 415-441.

PIETERSE, A. N., VAN KNIPPENBERG, D. \& VAN DIERENDONCK, D. 2013. Cultural diversity and team performance: The role of team member goal orientation. Academy of Management Journal, 56, 782-804.

PORTER, B. 1993. An Empirical Study of the Audit Expectation-Performance Gap. Accounting and Business Research, 24, 49-68.

POWER, M. 1999. The Audit Society: Rituals of Verification Oxford, Oxford University Press.

POWER, M. 2000. The audit society-Second thoughts. International Journal of Auditing, 4, 111-119.

POWER, M. K. 2003. Auditing dan the production of legitimacy. Accounting, Organizations and Society, 28, $379-394$.

PRATT, J. \& JIAMBALVO, J. 1981. Relationships between leader behaviors and audit team performance. Accounting, Organizations and Society, 6, 133-142.

PRAWITT, D. F. 1995. Staffing assignments for judgment-oriented audit tasks: The effects of structured audit technology and environment. Accounting Review, 443-465.

PUTNAM, L. L., FAIRHURST, G. T. \& BANGHART, S. 2016. Contradictions, Dialectics, and Paradoxes in Organizations: A Constitutive Approacht. The Academy of Management Annals, 10, 65-171.

RADCLIFFE, V. S. 1997. Competing rationalities in "special" government audits: The case of NovAtel. Critical Perspectives on Accounting, 8, 343-366.

RHODE, J. G. 1978. The Independent auditor's work environment. New York: Comission on Auditors' Responsibilities.

RICH, J. S., SOLOMON, I. \& TROTMAN, K. T. 1997. The audit review process: A characterization from the persuasion perspective. Accounting, Organizations and Society, 22, 481-505.

RITCHIE, J., SPENCER, L. \& O'CONNOR, W. 2003. Carrying out Qualitative Analysis. In: RITCHIE, J. \& LEWIS, J. (eds.) Qualitative Research Practice: A Guide for Social Science Students and Researchers. London: Sage.

SCHAD, J., LEWIS, M., RAISCH, S. \& SMITH, W. 2016. Paradox research in management science: Looking back to move forward. The Academy of Management Annals, 10, 564.

SCHNEIDER, K. J. 1990. The paradoxical self: Toward an understanding of our contradictory nature, New York, Insight Books.

SIKKA, P., PUXTY, A., WILLMOTT, H. \& COOPER, C. 1998. The impossibility of eliminating the expectations gap: Some theory and evidence. Critical Perspectives on Accounting, 9, 299-330.

SKAERBAEK, P. 2009. Public sector auditor identities in making efficiency auditable: The National Audit Office of Denmark as independent auditor and modernizer. Accounting, Organizations and Society, 34, 971-987.

SMITH, A. C. \& GRAETZ, F. 2006. Complexity theory and organizing form dualities. Management Decision, 44, 851-870.

SMITH, K. \& BERG, D. 1997. Cross-cultural groups at work. European Management Journal, $15,8-15$.

SMITH, K. J., DERRICK, P. L. \& KOVAL, M. R. 2010. Stress and its antecedents and consequences in accounting settings: An empirically derived theoretical model. Advances in Accounting Behavioral Research, 13, 113-142. 
SMITH, K. K. \& BERG, D. N. 1987. Paradoxes of Group Life: Understanding Conflict, Paralysis, and Movement in Group Dynamics, San Fransisca, Jossey-Bass.

SMITH, W. K. \& LEWIS, M. W. 2011. Toward A Theory Of Paradox: A Dynamic Equilibrium Model Of Organizing. Academy of Management Review, 36, 381-403.

SMITH, W. K. \& TRACEY, P. 2016. Institutional complexity and paradox theory: Complementarities of competing demands. Strategic Organization, 14, 455-466.

SMITH, W. K. \& TUSHMAN, M. L. 2005. Managing strategic contradictions: A top management model for managing innovation streams. Organization Science, 16, 522-536.

SOLOMON, I. 1987. Multi-auditor judgment/decision making research. Journal of Accounting Literature, 6, 1-25.

SRIKANTH, K., HARVEY, S. \& PETERSON, R. 2016. A Dynamic Perspective on Diverse Teams: Moving from the Dual-Process Model to a Dynamic Coordination-based Model of Diverse Team Performance. The Academy of Management Annals, 10, 453-493.

SUDDABY, R., GENDRON, Y. \& LAM, H. 2009. The organizational context of professionalism in accounting. Accounting, Organizations and Society, 34, 409-427.

SUNDARAMURTHY, C. \& LEWIS, M. W. 2003. Control and Collaboration: Paradoxes of Governance. Academy of Management Review, 26, 397-415.

SWEENEY, B. \& MCGARRY, C. 2011. Commercial and professional audit goals: Inculcation of audit seniors. International Journal of Auditing, 15, 316-332.

SWEENEY, B. \& PIERCE, B. 2004. Management control in audit firms: A qualitative examination. Accounting, Auditing \& Accountability Journal, 17, 779-812.

SWEENEY, B. \& PIERCE, B. 2006. Good hours, bad hours and auditors' defence mechanisms in audit firms. Accounting, Auditing \& Accountability Journal, 19, 858-892.

SWEENEY, B. \& PIERCE, B. 2011. Audit team defence mechanisms: auditee influence. Accounting and business research, 41, 333-356.

TROTMAN, K. T., SIMNETT, R. \& KHALIFA, A. 2009. Impact of the type of audit team discussions on auditors' generation of material frauds. Contemporary Accounting Research, 26, 1115-1142.

TURLEY, S. \& COOPER, M. 1991. Auditing in the United Kingdom: a study of development in the audit methodologies of large accounting firms, London, Prantice Hall.

VERA-MUNOZ, S., HO, J. \& CHOW, C. 2006. Enhancing knowledge sharing in public accounting firms. Accounting Horizons, 20, 133-155.

VINCE, R. \& BROUSSINE, M. 1996. Paradox, defense and attachment: Accessing and working with emotions and relations underlying organizational change. Organization Studies, $17,1-21$.

WATKINS, A. L., HILLISON, W. \& MORECROFT, S. E. 2004. Audit quality: A synthesis of theory and empirical evidence. Journal of accounting literature, 23, 153.

YUEN, D. C. Y., LAW, P. K. F., LU, C. \& GUAN, J. Q. 2013. Dysfunctional auditing behaviour: empirical evidence on auditors' behaviour in Macau. International Journal of Accounting and Information Management, 21, 209-226.

\section{Appendices}

Table 1 Detail Respondents

\begin{tabular}{|c|c|l|c|c|c|}
\hline Audit & \multirow{2}{*}{ Audit Team } & \multirow{2}{*}{ Duration } & \multicolumn{3}{|c|}{ Observation Phases } \\
\cline { 4 - 6 } Organisation & & & Interim* & Substantive $^{\#}$ & Total $^{*}$ \\
\hline IAB & Audit Team 1 & In days & 0 & 8 & 8 \\
\hline
\end{tabular}


Table 2 Interviews with Auditors

\begin{tabular}{|l|l|l|l|l|l|l|}
\hline \hline Audit Team & & $\begin{array}{l}\text { Manager/ } \\
\text { Auditor in } \\
\text { Charge }\end{array}$ & Supervisor & $\begin{array}{l}\text { Team } \\
\text { Leader }\end{array}$ & $\begin{array}{l}\text { Team } \\
\text { Member }\end{array}$ & Total \\
\hline \hline Audit Team 1 & Position & 2 & 1 & 1 & 4 & 9 \\
& Interviewees & $\mathbf{0}$ & $\mathbf{1}$ & $\mathbf{1}$ & $\mathbf{3}$ & $\mathbf{5}$ \\
\hline Audit Team 2 & Position & 2 & 1 & 1 & 4 & 8 \\
& Interviewees & $\mathbf{1}$ & $\mathbf{1}$ & $\mathbf{1}$ & $\mathbf{1}$ & $\mathbf{4}$ \\
\hline Audit Team 3 & Position & 2 & 1 & 1 & 4 & 6 \\
& Interviewees & $\mathbf{0}$ & $\mathbf{1}$ & $\mathbf{0}$ & $\mathbf{1}$ & $\mathbf{2}$ \\
\hline Audit Team 4 & Position & 2 & 1 & 1 & 3 & 7 \\
& Interviewees & $\mathbf{1}$ & $\mathbf{1}$ & $\mathbf{1}$ & $\mathbf{3}$ & $\mathbf{3}$ \\
\hline Audit Team 5 & Position & 2 & 1 & 1 & 6 & 10 \\
& Interviewees & $\mathbf{0}$ & $\mathbf{0}$ & $\mathbf{1}$ & $\mathbf{5}$ & $\mathbf{6}$ \\
\hline Others & Interviewees & $\mathbf{2}$ & $\mathbf{1}$ & $\mathbf{1}$ & $\mathbf{4}$ & $\mathbf{8}$ \\
\hline \hline Total Interviewees & $\mathbf{4}$ & $\mathbf{5}$ & $\mathbf{5}$ & $\mathbf{1 7}$ & $\mathbf{3 1}$ \\
\hline \hline
\end{tabular}

Table 3 Interviews with Non-Auditors

\begin{tabular}{|l|l|l|}
\hline \hline \multirow{5}{*}{ Auditees } & Respondents & $\begin{array}{l}\text { Number of } \\
\text { Interviewees }\end{array}$ \\
\hline \hline \multirow{5}{*}{ Other Divisions } & Auditee from Audit Tim 1 & 1 \\
\cline { 2 - 3 } & Auditee from Audit Tim 2 & 1 \\
\cline { 2 - 3 } & Other Auditees & 4 \\
\cline { 2 - 3 } & Total & 6 \\
\hline \hline \multirow{5}{*}{ Other Stakeholders } & Internal Audit Division Manager & 3 \\
\cline { 2 - 3 } & Training Centre Division Manager & \\
\cline { 2 - 3 } & Human Resource Division Manager & 1 \\
\cline { 2 - 3 } & Research and Development Division Manager \\
\cline { 2 - 3 } & Finance Division Manager & 1 \\
\cline { 2 - 3 } & Total & 2 \\
\hline \hline \multirow{5}{*}{ Other Internal Government Auditors } & $\mathbf{8}$ \\
\cline { 2 - 3 } & Private Sector Audit Profession & 2 \\
\cline { 2 - 3 } & Member of Parliament & 1 \\
\hline
\end{tabular}




\begin{tabular}{|l|l|l|}
\hline & Common Citizen & 1 \\
\cline { 2 - 3 } & Total & 5 \\
\hline \hline & TOTAL & 19 \\
\hline \hline
\end{tabular}

\section{Table 4 Issues with Team Cohesion}

\begin{tabular}{|c|c|c|}
\hline Team & $\begin{array}{l}\text { Context of } \\
\text { observation }\end{array}$ & Issues with Team Cohesion \\
\hline A & $\begin{array}{l}\text { Audit of a provincial } \\
\text { health service } \\
\text { provider }\end{array}$ & $\begin{array}{l}\text { There appeared to be a lack of coordination among team members. } \\
\text { Auditors are working in insolation. The lack of communication among the } \\
\text { sub teams influenced their approach. At times the client auditees are } \\
\text { asked about the same matter and documents by different sub teams. }\end{array}$ \\
\hline B & $\begin{array}{l}\text { Audit of a regional } \\
\text { province }\end{array}$ & $\begin{array}{l}\text { It appeared difficult for the team to develop an agreed plan. Some } \\
\text { members suggested an audit plan to control a subjective approach in } \\
\text { selecting evidence. Others felt it was impractical to carefully consider } \\
\text { materiality and risk in selecting audit evidence. Some inexperience } \\
\text { auditors were perceived to be a burden on the teams work. }\end{array}$ \\
\hline C & $\begin{array}{l}\text { Audit at a } \\
\text { municipality }\end{array}$ & $\begin{array}{l}\text { Team members with diverse experiences and skills found difficulty in } \\
\text { developing effective teamwork and cohesion. Some auditors choose to } \\
\text { elect to do extra work rather than working with inexperience colleague or } \\
\text { those who do not have the same background. Some inexperienced } \\
\text { auditors were somewhat excluded rather brought into the team. } \\
\text { Communication with senior members was very limited. }\end{array}$ \\
\hline D & $\begin{array}{l}\text { Audit of a state-own } \\
\text { enterprise }\end{array}$ & $\begin{array}{l}\text { Different approaches were taken by individual team members, as most of } \\
\text { the team were not familiar with the audit context. Inexperience auditors } \\
\text { coordinated ineffectually with other members. The team exhibited a lack } \\
\text { of planning and coordination to develop proper procedure. }\end{array}$ \\
\hline E & $\begin{array}{l}\text { Audit at a national } \\
\text { custom office }\end{array}$ & $\begin{array}{l}\text { Team members' approach in selecting evidence varied. Some selected } \\
\text { evidence based on convenience without coordination with other } \\
\text { members of the team. There were very limited discussions or monitoring } \\
\text { on the approach to complete the review. }\end{array}$ \\
\hline
\end{tabular}

